\title{
TINJAUAN UMUM PERILAKU HEWAN DI INDONESIA DAN INTEGRASI KEILMUANNYA
}

\author{
Syarif Hidayat Amrullah*, Dirhamzah, Aswar Rustam, Hasyimuddin \\ Jurusan Biologi \\ Fakultas Sains dan Teknologi UIN Alauddin Makassar \\ Jl. Sultan Alauddin No. 63, Kabupaten Gowa, Sulawesi Selatan. 92113 \\ *E-mail: syarifhidayat.amrullah@gmail.com
}

\begin{abstract}
Abstrak: Hewan merupakan salah satu dari kerajaan dalam sistematika makhluk hidup di bawah Domain Eukarya. Perilaku didefinisikan sebagai aksi atau tindakan yang dapat mengubah pola hubungan atau interaksi antara suatu organisme dengan lingkungannya. Perilaku hewan meliputi tindakan, aktivitas; agresi; suara hewan; penerbangan mencari makan; berburu; bahasa; belajar; perkawinan; gerakan; bermain; refleks; tanggapan; menyusui; renang; simbiosis: territorial; mengibas sayap, dan lain sebagainya. Studi tentang perilaku hewan dikenal dengan sebutan etologi. Keanekaragaman genetik, jenis, dan ekosistem yang dimiliki oleh setiap individu hewan yang berbeda akan menyebabkan perilaku yang berbeda pula dalam menanggapi stimulus yang ada, baik dari dalam tubuh maupun dari lingkungan di sekitarnya. Perilaku hewan di Indonesia antara lain: perilaku nyamuk menghisap darah sekaligus menjadi vektor penyakit seperti filariasis, perilaku bertahan bulu babi dan perilaku kawin teripang, perilaku berjemur (istirahat) pada buaya, perilaku mencari makan dan menghidupi keluarga pada burung julang, perilaku dewasa dan pradewasa pada rusa, perilaku harimau di habitat asli dan buatan, serta perilaku reproduksi dan pengasuhan pada primata. Meskipun hewan selalu diasosiakan sebagai makhluk rendah daripada manusia sesungguhnya darinya banyak pelajaran hidup yang bisa dipetik. AlQuran mengisyaratkan bahwa kita bisa belajar dari hewan. Dalam surah anNahl (16) ayat 66 Allah swt. Berfirman: "Sesungguhnya pada hewan ternak ada pelajaran bagimu". Bahkan manusia dari awal sudah belajar dari hewan, berupa burung. Hal tersebut tergambar dalam Surah al-Maidah (5) ayat 31 yang menyatakan, "Maka Allah mengutus burung gagak menggali tanah untuk menunjukkan kepadanya cara mengubur mayat saudaranya".
\end{abstract}

Kata Kunci: al-Quran, hewan, perilaku

\section{PENDAHULUAN}

$\mathrm{H}$ ewan (Latin: Animalia) merupakan salah satu dari kerajaan (Kingdom) dalam sistematika makhluk hidup di bawah Domain Eukarya. Menurut Zulfikar (2018), hewan (fauna atau hewan) dalam al-Qur'an ditemukan dalam term daabbah dan al-an'aam yang masing-masing disebutkan sebanyak 18 dan 32 kali. Kata daabbah atau dawwaab, memiliki tiga makna: (1) ditujukan kepada khusus hewan; (2) ditujukan kepada hewan dan manusia; dan (3) ditujukan kepada hewan, manusia, dan jin. Sedangkan kata al-an'aam berarti harta benda yang digembalakan. Fungsi an'aam dapat berupa alat pengangkutan, dapat diminum susunya, dapat dimakan dagingnya, serta dapat dipakai 
sebagai hiasan dan pakaian yang berasal dari bulu/rambutnya.

Perilaku didefinisikan sebagai aksi atau tindakan yang dapat mengubah pola hubungan atau interaksi antara suatu organisme dengan lingkungannya. Studi mengenai perilaku pada dasarnya memiliki kaitan yang sangat erat dengan disiplin ilmu lain. Misalnya, studi mengenai fungsi perilaku berkaitan dengan aspek ekologi dan aspek sosiologi. Terdapat dua pendapat tentang perilaku; merupakan reaksi terhadap stimulus eksternal, sedangkan perilaku spontan dipengaruhi oleh faktor internal, misalnya faktor motivasi (Suhara, 2010). Menurut Barrows (2001), perilaku hewan meliputi tindakan, aktivitas; agresi; suara hewan; penerbangan mencari makan; berburu; bahasa; belajar; perkawinan; gerakan; bermain; refleks; tanggapan; menyusui; renang; simbiosis: teritorial; serta mengibas sayap, dan lain sebagainya. Studi tentang perilaku hewan dikenal dengan sebutan etologi. Bidang ilmu ini mengkaji secara objektif tentang perilaku hewan dalam berbagai kondisi lingkungan, serta melihat perilaku tersebut sebagai respon adaptif dan evolusioner (Rudiansyah \& Radhi, 2019).

Bentang alam Indonesia di antara Asia dan Australasia membentuk garis Wallacea dan garis biogeografi, seperti garis Weber dan Lydekker sehingga menyebabkan Indonesia memiliki keanekaragaman hayati yang sangat tinggi. Megabiodiversitas Indonesia berada di tiga besar dunia bersama Brazil dan Zaire. Hingga tahun 2014, telah tercatat 8.157 jenis fauna vertebrata (ikan, herpetofauna, burung, dan mamalia) dan 1.900 jenis kupu-kupu (10\% dari total jenis di dunia). Selain itu, keunikan geologi yang dimiliki Indonesia menyebabkan tingginya endemisitas. Fauna endemik Indonesia sangat tinggi, bahkan untuk beberapa kelompok seperti reptil, burung, dan mamalia memiliki endemisitas tertinggi di dunia. Jumlah jenis fauna endemik Indonesia terdiri dari 280 jenis ikan, 204 jenis amphibia, 328 jenis reptil, 386 jenis burung, dan 270 jenis mamalia (Widjaja et al., 2014). Keanekaragaman genetik, jenis, dan ekosistem yang dimiliki oleh setiap individu hewan yang berbeda akan menyebabkan perilaku yang berbeda pula dalam menanggapi stimulus yang ada, baik dari dalam tubuh maupun dari lingkungan di sekitarnya. Artikel ini akan memberikan gambaran singkat mengenai beberapa contoh perilaku dari kelompok hewan yang ada di Indonesia.

\section{PERILAKU SERANGGA (NYAMUK)}

Nyamuk merupakan salah satu kelompok serangga vektor yang dapat menyebarkan penyakit pada manusia. Salah satu contohnya adalah Genus Mansonia yang menjadi vektor penyakit filariasis atau lebih dikenal dengan kaki gajah. Hasil penelitian Supriyono et al. (2017) menunjukkan bahwa dari lima jenis nyamuk, yaitu Mansonia annulata, Ma. annulifera, Ma. bonneae, Ma. dives, dan Ma. uniformis, jenis Ma. uniformis yang paling banyak ditemukan di dalam rumah $(37,99 \%)$ dengan puncak penghisapan darah yaitu pada pukul 20:00 s.d. 20:45, sedangkan jenis Ma. dives banyak tertangkap di luar rumah (56,80\%) dengan puncak penghisapan darah pada pukul 19:00 s.d. 19:45. Penelitian ini juga melibatkan delapan ekor kucing sebagai reservoar yang terinfeksi mikrofilaria dari hasil pemeriksaan darahnya. Perilaku yang teramati adalah perilaku makan (foraging behavior) dari genus nyamuk tersebut, pemilihan waktu, dan jumlah anggota populasi dalam rumah menunjukkan bahwa nyamuk mansonia ini mencari makan secara berkelompok.

Nyamuk lain yang menjadi vektor filariasis adalah Culex sp., bahkan menjadi yang utama dan paling dominan. Melalui penelitian dengan memanfaatkan umpan manusia dan kambing, diperoleh waktu penghisapan antara pukul 19:00 s.d. 04.00 dini hari. Faktor stimulus lain yang turut memengaruhi berupa temperatur $\left(27-30^{\circ} \mathrm{C}\right)$, kelembaban antara 
99 s.d. $100 \%$, intensitas cahaya 60-65 lux, serta kecepatan angin 3-5 km/jam (Sukendra \& Shidqon, 2016).

Selain perilaku mencari makan, perilaku yang dapat diamati dari kehidupan nyamuk adalah perilaku bertelur. Wurisastuti (2013) menyimpulkan bahwa terdapat perubahan perilaku bertelur dari nyamuk jenis Aedes aegypti, yang sebelumnya dikenal tidak menyukai bertelur di air tercemar. Hasil penelitiannya menunjukkan bahwa nyamuk jenis ini juga menyukai bertelur pada media air yang tercemar sekalipun, seperti air yang tercemar kotoran sapi. Penelitian serupa dengan membandingkan media air tercemar lainnya menunjukkan bahwa nyamuk $A$. aegypti ini pun menyukai media air eceng gondok, dan air lindi, sedangkan pada media air limbah cair tahu dan limbah laundry sebaliknya, tidak ada telur yang diletakkan (Agustin et al., 2017).

Nyamuk disebutkan dalam al-Qur'an pada surah al-Baqarah ayat 26 sebagai perumpamaan untuk orang-orang kafir. Untuk kelompok serangga yang digambarkan hidup berkelompok lebih banyak dalam al-Qur'an adalah semut pada surah an-Naml ayat 18 dan lebah pada surah an-Nahl ayat 68-69 (Jasmi \& Mat Udin, 2013). Penyebutan nyamuk pada surah al-Baqarah tersebut merupakan tanggapan atas komentar orang-orang kafir mengenai surah al-Ankabut yang mengatakan "untuk apa Tuhan menyebutkan tentang laba-laba, hewan ukuran kecil di dalam kitab suci umat Islam? Sebagai jawaban Allah menciptakan hewan yang lebih kecil dari itu, yaitu berupa nyamuk, Allah tidak malu. Qatadah menafsirkan bahwa nyamuk dipilih sebagai misal karena hewan ini lemah, kecil dan pendek umurnya, untuk mengingatkan manusia yang terpaku pada hidup di dunia yang singkat dan hina. Kitab-kitab tafsir klasik yang lain juga menyimpulkan tujuan ayat sekitar hal itu, padahal penyebutan kalimat "fama fawqaha" yakni "sesuatu yang lebih kecil dari itu" setelah penyebutan kata nyamuk adalah isyarat untuk mentafakkuri penciptaan nyamuk serta mempelajari manfaat yang dapat diperoleh manusia atas penciptaan hewan yang dikenal sebagai pembawa penyakit malaria dan demam berdarah ini (Pranggono, 2005).

\section{PERILAKU ECHINODERMATA (BULU BABI DAN TERIPANG)}

Bulu babi banyak digunakan sebagai bioindikator pencemaran laut. Perilaku yang dapat diamati dalam kehidupannya berupa perilaku bergerak dan beristirahat (moving and resting). Deadema setosum adalah salah satu invertebrata laut yang memilki sensitivias tinggi terhadap logam berat, seperti Kadmium (Cd). Respon perilaku berpindah dan beristirahat dari hewan jenis ini sebagai respon terhadap paparan unsur Kadmium adalah perpindahannya semakin lambat dan perilaku beristirahat semakin lama di konsentrasi logam berat $\mathrm{Cd}$ tinggi. Hal tersebut diakibatkan oleh akumulasi logam berat $\mathrm{Cd}$ dalam tubuh yang terakumulasi melalui proses penyerapan. Sedangkan untuk behavior end point, bulu babi mengalami perubahan morfologis, seperti pelepasan/penutupan duri (spine closure) (Rumahlatu, 2012).

Echinodermata lain yang banyak bermanfaat adalah teripang (Holothuria scabra). Jenis ini memiliki nilai ekonomis tinggi karena dapat dimanfaatkan sebagai bahan pangan dan juga obat-obatan. Perilaku pemijahan dalam perkembangbiakannya terlihat bahwa induk jantan bertumpu pada bagian posterior (belakang), mengangkat tinggi bagian anterior yang terdapat tonjolan, kemudian mengeluarkan sperma yang tampak seperti asap berwarna putih di dalam air. 10 menit kemudian, terlihat seekor induk betina dengan suhu dan cara yang sama mengeluarkan sel telur. Pembuahan pun terjadi secara eksternal (di luar tubuh) (Narayaman, 2014).

Perilaku bertahan dari kondisi lingkungan yang terpapar logam berat, menunjukkan 
pentingnya ikhtiar ketika menghadapi bahaya. Sama halnya dalam masa pandemi Covid19. Menghindar dari bahaya tidak hanya terjadi pada manusia yang dibekali akal pikiran, tetapi hewan pun secara naluriah akan menghindari bahaya yang mengancam hidupnya. Salah satu hewan yang menjadi contoh disebutkan langsung dalam al-Quran adalah binatang semut. Dalam al-Quran Surah An-Naml (27): 18 disebutkan: "Hingga apabila mereka sampai di lembah semut berkatalah seekor semut: Hai semut-semut, masuklah ke dalam sarang-sarangmu, agar kamu tidak diinjak oleh Sulaiman dan tentaranya, sedangkan mereka tidak menyadari".

Perilaku perkawinan yang dimulai dengan inisiatif dari induk jantan juga dijelaskan dalam al-Quran dan Hadis. Dalam kehidupan manusia dalam hal perkawinan juga menunjukkan dominasi kaum laki-laki. Dalam hal kawin mawin atau berhubungan suami istri misalnya, sekalipun dalam Agama Islam dalam beberapa hadis disebutkan bahwa betapa besarnya pahala yang diperoleh oleh seorang istri jika ia yang terlebih dahulu mengajak suaminya berhubungan, tetap saja dalam prakteknya amat sedikit kaum istri yang melakukannya, justru kaum laki-lakilah yang lebih dominan memulai. Hal demikian tidak lepas dari kodrati seorang wanita yang dalam bahasa Al-Quran dianggap sebagai ladang sementara kaum laki-laki dianggap sebagai penggarap. Demikian dalam bahasa Al-Quran objek perintah menikah atau kawin memang ditujukan bagi kaum lakilaki.

\section{PERILAKU REPTIL (BUAYA)}

Perilaku harian buaya muara meliputi perilaku makan, sosial, berjemur/istirahat, dan pergerakan. Sebuah penelitian menggunakan buaya jantan dominan (dinamai Monti) dan buaya betina dominan (Bunda) menunjukkan bahwa buaya dominan menunjukkan perilaku yang lebih kompleks, namun untuk jantan dan betinanya tidak ada perbedaan pola perilaku harian. Baik jantan, maupun betina melakukan pergerakan, istirahat dengan berjemur, melakukan interaksi sosial dengan individu lain dalam populasinya, serta melakukan perilaku makan (Setio et al., 2010).

Salah satu jenis hewan yang paling banyak dikonotasikan negatif adalah buaya (Crocodilus porosus). Konotasi tersebut untuk menggambarkan perilaku manusia yang pemalas dan rakus yang hanya memiliki rutinitas makan dan istirahat. Padahal perilaku buaya tidak melulu hanya makan dan berjemur/istirahat melainkan juga melakukan interaksi sosial kepada sesamanya. Perilaku tersebut menggambarkan bahwa reptil sejenis buaya adalah suatu komunitas seperti hal manusia.

\section{PERILAKU BURUNG (JULANG SULAWESI DAN JULANG EMAS)}

Kelas Aves merupakan kelompok terbesar dalam Vertebrata (hewan bertulang belakang). Habitatnya mencakup berbagai macam ekosistem, baik alami maupun buatan. Julang Sulawesi (Rhyticeros cassidix) merupakan salah satu satwa endemik yang berasosiasi dengan menjadikan pohon beringin, pala hutan, dan kenari sebagai makanannya. Hal ini dikuatkan oleh Bamotiwa et al. (2014), dalam penelitiannya yang mengungkapkan bahwa jenis pohon yang berasosiasi dengan julang sulawesi adalah beringin dengan nilai asosiasi (11.91), nantu (4.34), dan malopaga (4.96).

Tentang perilaku makannya, dapat dilihat pada saudara serumpun, yakni julang emas (Rhyticeros undulates), di Gunung Ungaran Jawa Tengah. Julang emas jantan memberikan makan kepada induk betina sebanyak 1-4 kali sehari dengan memuntahkan buah pakan yang didapatkan ke ujung paruh betina di dalam sarang. Dalam sekali kunjungan membawa makanan, julang emas jantan mampu membawa 2-48 buah di dalam 
kantung lehernya. Waktu paling sering berkisar pada pukul 15:00 s.d. 16:00 dengan laju pemberian makan sebanyak 9-10 buah per menit. Adapun jenis buah yang paling banyak dimakan oleh julang emas ini adalah dari anggota Famili Lauraceae dan Moraceae (Dahlan \& Rahayuningsih, 2015).

Perilaku hewan di atas menunjukkan bahwa sebagai jantan atau laki-laki wajib memenuhi kebutuhan/nafkah untuk keluarga. Hal tersebut mirip dengan tata kehidupan umat manusia, khususnya umat Islam yang memposisikan laki-laki sebagai kepala keluarga yang berkewajiban menafkahi keluarga, yang terdiri dari istri dan anak-anaknya. Kelompok burung-burung sebagai sebuah komunitas yang serupa manusia disebutkan dalam Al-Quran Surah al-An'am (6) ayat 38, "Dan tidaklah hewan melata di bumi dan burung-burung yang terbang dengan sayapnya di udara kecuali mereka merupakan umat semisal kamu". Kehadiran burung-burung dengan segala perilakunya tersebut dapat dijadikan pelajaran oleh manusia, khususnya kaun suami agar tidak abai terhadap kewajiban dan tanggung jawabnya memberi nafkah.

\section{PERILAKU MAMMALIA (RUSA DAN HARIMAU)}

Cervus timorensis (rusa timor) adalah salah satu jenis yang dilindungi di Indonesia dengan status rentan terhadap perburuan liar. Aktivitas yang dilakukan di Taman Satwa Lembah Hijau, Bandar Lampung meliputi: istirahat, makan, minum, berjalan, bersuara, urinasi, defekasi, dan tidur. Pengamatan perilaku dari subspesies ini, yakni rusa timor jantan dewasa, betina dewasa, jantan anakan, dan betina anakan menunjukkan perbedaan perilaku harian yang dominan. Rusa timor jantan dewasa dominan melakukan aktivitas istirahat, sedangkan jantan anakan banyak melakukan aktivitas makan. Rusa timor betina anakan banyak melakukan aktivitas berjalan (Putra, 2016). Perilaku sosial pada rusa jenis lain yang serumpun, yakni Cervus unicolor (rusa sambar) menunjukkan beberapa perilaku tambahan: menjilati bulu (grooming) yang paling besar dilakukan oleh rusa betina; interaksi bergesek tanduk, dominan dilakukan rusa jantan; sedangkan interaksi mendekati dan menjauhi manusia dilakukan secara dominan masing-masing oleh rusa jantan dan betina (Gusmalinda, 2017).

Berdasarkan perilaku rusa di atas, dapat dianalogikan sebagai perbedaan antara individu dewasa dan pradewasa. Dewasa cenderung mengutamakan efektivitas, sedangkan pradewasa memaksimalkan energi yang melimpah untuk beraktivitas. Perilaku demikian sama halnya dengan kehidupan manusia. Saat masih usia muda, manusia lebih banyak mengandalkan kekuatan fisik sebaliknya ketika sudah memasuki usia dewasa hingga lansia mereka lebih banyak mengandalkan pengalamannya seiring dengan menurunnya kekuatan fisiknya. Kondisi demikian telah digambarkan Al-Quran dalam surah Ar-Rum (30): 54 yang menyebutkan "Allah, dialah yang menciptakan kamu dari keadaan lemah, Kemudian dia menjadikan (kamu) sesudah keadaan lemah itu menjadi kuat, Kemudian dia menjadikan (kamu) sesudah Kuat itu lemah (kembali) dan beruban. Dia menciptakan apa yang dikehendaki-Nya dan Dialah yang Maha mengetahui lagi Maha Kuasa”.

Perilaku jantan yang cenderung mendekati manusia, dan betina dengan perilaku sebaliknya yaitu menjauhi manusia dapat menggambarkan agresivitas. Sama seperti manusia, sekalipun laki-laki dan perempuan sama-sama dibekali akal pikiran dan potensi yang sama oleh Allah Swt, tetap saja laki-laki atau seorang suami secara kodrati diberi kelebihan-kelebihan yang tidak dimiliki oleh seorang wanita. Atas kelebihan itulah seorang laki-laki/suami didaulat sebagai pemimpin atas kaum wanita. Dalam al-Quran surah An-Nisa (4) ayat 34 disebutkan; "Kaum laki-laki itu adalah pemimpin bagi kaum 
wanita, oleh karena Allah telah melebihkan sebahagian mereka (laki-laki) atas sebahagian yang lain (wanita), dan karena mereka (laki-laki) telah menafkahkan sebagian dari harta mereka. sebab itu maka wanita yang saleh, ialah yang taat kepada Allah lagi memelihara diri ketika suaminya tidak ada, oleh karena Allah telah memelihara (mereka), wanita-wanita yang kamu khawatirkan nusyuznya. Maka nasehatilah mereka dan pisahkanlah mereka di tempat tidur mereka, dan pukullah mereka".

Penelitian tentang mamalia jenis lain oleh Ganesa \& Aunurohim (2012) dengan hewan objek harimau sumatera menunjukkan pola perilaku dominan yang sama. Pada habitat ex situ di Kebun Hewan Surabaya, Panthera tigris sumatrae melakukan aktivitas istirahat, perilaku sosial, perilaku makan, dan perilaku lainnya dengan persentase masingmasing $(74.9 \%, 2.86 \%, 1.5 \%$, dan $20.74 \%)$. Lebih lanjut dijelaskan bahwa perilaku harian, baik in situ maupun ex situ memiliki kesamaan. Meski sebenarnya harimau akan lebih bebas di habitat aslinya, namun kedua jenis konservasi ini memiliki tujuan utama demi menyelamatkan jenis tersebut dari kepunahan akibat perburuan liar. Manusia jelas memegang peranan penting dalam konservasi, sebagai bagian dari implementasi perwujudan kekhalifahan manusia di muka bumi (QS. al-Baqarah/2; 30) dan mencegah pelaku pemburuan dari kalangan manusia yang serakah sebagai perwujudan atas larangan Allah untuk tidak berbuat kerusakan: "Dan janganlah kamu berbuat kerusakan di bumi setelah (diciptakan) dengan baik" (QS. al-A'raaf /7: 56). Perintah memperlakukan hewan dengan baik juga disebut dalam QS An-Nur ayat 41 bahwa "Tidakkah engkau (Muhammad) tahu bahwa kepada Allah-lah bertasbih apa yang ada di langit dan bumi, dan juga burung-burung yang mengembangkan sayapnya. Masing-masing sungguh telah mengetahui cara berdoa dan bertasbih".

\section{PERILAKU PRIMATA (MONYET EKOR PANJANG DAN MONYET HITAM SULAWESI)}

Primata merupakan ordo yang mencakup monyet, kera, gorila, orangutan, simpanse, dan manusia. Merupakan hewan yang memiliki perkembangan otak paling baik, dengan korteks serebral yang sangat besar. Umumnya anggota ordo ini bersifat arboreal, dengan mata besar, penglihatan binokular, tangan yang dapat menggenggam, dan lima jari (biasanya dengan kuku rata) di kedua kaki depan dan kaki belakang. Terdapat hipotesis yang menyatakan bahwa kemampuan dan keahlian primata yang tinggal di pohon dalam menangkap mangsa atau menghindari musuh sebagian besar bertanggung jawab atas kemajuan mereka dalam struktur otak (Hickman et al., 2017).

Monyet ekor panjang (Macaca fascicularis) misalnya, memiliki kompleksitas perilaku yang lebih tinggi dibanding hewan-hewan yang telah dibahas sebelumnya. Perilaku hariannya meliputi: bergerak (dengan persentase 35\%), menjilati bulu/grooming $(25 \%)$, bermain $(15 \%)$, beristirahat (10\%), makan/foraging (6.8\%), agonistik (3.6\%), tidur $(2.3 \%)$, kawin $(0.9 \%)$, dan bersuara $(0.8 \%)$ (Saputra et al., 2015). Khusus untuk perilaku makan saja Ordo Primata dipengaruhi oleh banyak faktor, seperti ukuran tubuh, kondisi gigi, dan organ pencernaan lainnya, ketersediaan dan pengetahuan tentang pakan, indera penglihatan, perubahan musim, hirarki dan struktur sosial, kepadatan populasi, dan kompetisi untuk memperebutkan sumber daya berupa makanan (Karyawati, 2012).

Salah satu dari tujuh jenis anggota Genus Macaca yang ada di Sulawesi, Macaca nigra, dalam bahasa setempat dikenal dengan "yaki", memiliki status konservasi Critically Endangered (terancam punah). Salah satu faktor kerentanan terhadap kepunahan adalah laju reproduksi yang lambat tidak seiring dengan kematian yang 
meningkat akibat hilangnya habitat untuk pembangunan, serta pertumbuhan populasi manusia dan pemburuan liar. Merespon ancaman tersebut, monyet ini menunjukkan perilaku reproduktif, terutama pada betina. $M$. nigra betina menunjukkan pola perilaku berbeda-beda pada saat siklus menstruasi, kehamilan, dan menyusui terutama untuk pemberian makan, mencari makan, gerak, dan istirahat. Perilaku makannya hanya menurun pasca melahirkan dan menyusui. Perilaku yang dominan di fase tersebut adalah istirahat untuk pemulihan kondisi fisik (Pasetha et al., 2019). Kedekatan anggota Ordo Primata lain dengan manusia terlihat dari tanggung jawab pengasuhan induk kepada anaknya. Hanya saja, musuh alami mereka adalah manusia yang serakah itu sendiri. Pelaku pengalihan fungsi lahan yang menjadi habitatnya, serta yang melakukan perburuan secara liar tak lain adalah manusia.

Perilaku manusia justru malah lebih banyak menimbulkan kerusakan di manamana, baik di darat maupun di laut, sebagaimana disebutkan dalam QS. Ar-Rum (30) ayat 41. Pada prosesnya hewan-hewan seringkali dijadikan perumpamaan untuk sifat buruk yang dimiliki manusia. Beberapa di antaranya digambarkan dalam al-Quran; seperti anjing (pada QS al-A'raf/7: 176), seperti hewan ternak (QS al-A'raf/7: 179), seperti kera (QS Al-Baqarah/2: 65), seperti babi (QS al-Maidah/5: 60), seperti laba-laba (QS alAnkabut/29: 41, seperti nyamuk (QS al-Baqarah/2: 26), dan seperti keledai (QS alJumuah/62: 5).

\section{KESIMPULAN}

Perilaku hewan merupakan respon terhadap stimulus di sekitarnya. Respon tersebut berbeda-beda karena setiap individu dalam taksonomi memiliki kemampuan berbedabeda dalam menanggapinya, baik secara anatomi maupun fisiologi. Perilaku hewan yang berasosiasi dengan manusia di Indonesia antara lain: perilaku nyamuk menghisap darah sekaligus menjadi vektor penyakit seperti filariasis, perilaku bertahan bulu babi dan perilaku kawin teripang, perilaku berjemur (istirahat) pada buaya, perilaku mencari makan dan menghidupi keluarga pada burung julang, perilaku dewasa dan pradewasa pada rusa, perilaku harimau di habitat asli dan buatan, perilaku reproduksi dan pengasuhan pada primata, dan perilaku-perilaku hewan lainnya. Manusia seharusnya mampu menempatkan diri sebagai khalifah di muka bumi dan pemuncak rantai makanan. Akal pikiran yang dikaruniakan oleh Tuhan sejatinya untuk membawanya ke arah yang lebih bijak dalam bertindak demi keberlanjutan semua makhluk. Selain itu, makhluk hidup seperti hewan meskipun selalu diasosiakan sebagai makhluk rendah daripada manusia sesungguhnya darinya banyak pelajaran hidup yang bisa dipetik.

\section{DAFTAR PUSTAKA}

Agustin, I., Tarwotjo, U., \& Rahadian, R. (2017). Perilaku bertelur dan siklus hidup Aedes aegypti pada berbagai media air. Jurnal Biologi, 6(4), 71-81.

Bamotiwa, D., Labiro, E., \& Ihsan, M. (2014). Asosiasi burung julang sulawesi (Rhyticeros cassidix) dengan jenis-jenis pohon di Kawasan Hutan Lindung Desa Ensa Kec. Mori Atas Kab. Morowali Utara. Warta Rimba, 2(2), 67-74.

Barrows, E. M. (2001). Animal Behavior Desk Referenece: a dictionary of animal behavior, ecology, and evolution. America (2nd ed.). Florida: CRC Press LLC.

Dahlan, J., \& Rahayuningsih, M. (2015). Perilaku makan julang emas (Rhyticeros undulatus) pada saat bersarang di Gunung Ungaran Jawa Tengah. Unnes Journal of Life Science, 4(1), 16-21.

Ganesa, A., \& Aunurohim. (2012). Perilaku harian harimau sumatera (Panthera tigris sumatrae) dalam konservasi ex-situ Kebun Binatang Surabaya. Jurnal Sains dan Seni ITS, 1(1), 48-53.

Gusmalinda, R., Dewi, B. S., \& Masruri, N. W. (2017). Perilaku sosial rusa sambar (Cervus unicolor) dan rusa totol (Axis axis) di kandang penangkaran PT Gunung Madu Plantations Lampung. Jurnal Sylva 
Lestari, 6(1), 74-84.

Hickman, C. P., Keen, S., Eisenhour, D., Larson, A., \& Anson, H. (2017). Integrated Principles of Zoology (17th ed.). New York: McGraw-Hill Education.

Jasmi, K. A., \& Mat Udin, S. (2013). Bootani, zoologi dan tenaga dari perspektif Al-Quran. Skudai, Johor Bahru: Universiti Teknologi Malaysia Press.

Karyawati, A. T. (2012). Tinjauan umum tingkah laku makan pada hewan primata. Jurnal Penelitian Sains, $15(1), 44-47$.

Narayaman, A. S. (2014). Perilaku pemijahan teripang pasir (Holothuria scabra) berdasarkan faktor lingkungan (suhu) di Desa Ohoi Letman Kecamatan Kei Kecil Kabupaten Maluku Tenggara. Biopendix, 1(1), 80-85.

Pasetha, A., Perwitasari-Farajallah, D., \& Gholib. (2019). Perilaku harian monyet hitam sulawesi (Macaca nigra) pada masa kebuntingan di Cagar Alam Tangkoko-Batuangus, Sulawesi Utara. Jurnal Sumberdaya Hayati, 5(1), 25-34.

Pranggono, H. (2005). Percikan sains dalam Al Quran: menggali inspirasi ilmiah. Jakarta: Niaga Swadaya.

Putra, W. D. (2016). Perilaku Harian Rusa Timor di Taman Satwa Lembah Hijau Bandar Lampung [Skripsi]. Lampung: Universitas Lampung.

Rudiansyah, R., \& Radhi, M. (2019). Perilaku satwa liar pada Kelas Burung (Aves). https://osf.io/preprints/dvph6/

Rumahlatu, D. (2012). Respon perilaku bulu babi Deadema setosum terhadap logam berat kadmium. Jurnal Bumi Lestari, 12(1), 45-54.

Saputra, A., Marjono, Puspita, D., \& Suwarno, S. (2015). Studi perilaku populasi monyet ekor panjang (Macaca fascicularis) di Taman Wisata Alam Grojogan Sewu Kabupaten Karanganyar. Bioeksperimen, 1(1), 6-11.

Setio, P. I., Muharromi, A. F., Prihantono, S., Qurniawan, T. F., Nugraha, A. P., \& Eprilurahman R. (2010). Perilaku harian buaya muara (Crocodylus porosus, Schneider 1801) di Pusat Penyelamatan Satwa Jogja. Biota Jurnal Ilmiah Ilmu-Ilmu Hayati, 15(2), 188-194.

Suhara. (2010). Ilmu kelakuan hewan (animal behaviour). Bandung: Jurusan Pendidikan Biologi FMIPA UPI.

Sukendra, D. M., \& Shidqon, M. A. (2016). Gambaran perilaku menggigit nyamuk Culex sp. sebagai vektor penyakit filariasis Wuchereria bancrofti. Pena Medika, 6(1), 19-33.

Supriyono, S., Tan, S., \& Hadi, U. K. (2017). Perilaku nyamuk mansonia dan potensi reservoar dalam penularan filariasis di Desa Gulinggang. Aspirator: Jurnal Penelitian Tular Vektor, 9(1), 1-10.

Widjaja, E. A., Rahayuningsih, Y., Rahajoe, J. S., Ubaidillah, R., Maryanto, I., Walujo, E. B., \& Semiadi, G. (2014). Kekinian Keanekaragaman Hayati Indonesia 2014. Jakarta: LIPI Press.

Wurisastuti, T. (2013). Perilaku bertelur nyamuk Aedes aegypti pada media air tercemar. Jurnal Biotek Medisiana Indonesia, 2(1), 25-31.

Zulfikar, E. (2018). Wawasan Al-Qur'an tentang ekologi (Kajian tematik ayat-ayat konservasi lingkungan). QOF , 2(2), 113-132. 